\title{
Factors Effecting The Incidence Of Anemia Among Adolescent Girls At Tatah Makmur
}

\section{South Kalimantan Public Health Center}

\author{
Agustina Hotma Uli Tumanggor*1 \\ ${ }^{1}$ Sari Mulia School of Health Sciences, Banjarmasin, 70233, Indonesia \\ * agustina@stikessarimulia.ac.id \\ Restiana Tumanggor ${ }^{2}$ \\ ${ }^{2}$ Tatah Makmur Public Health Center, Banjarmasin, 70248, Indonesia \\ restina_tumagor@gmail.com
}

\begin{abstract}
Objective: Anemia is a condition of low blood concentrations of hemoglobin or a low hematocrit. Adolescent girls who experience anemia often occur when menstruating due to iron-containing blood loss. Based on the above background, this study examines what factors are related to the incidence of anemia of adolescent girls in Tatah Makmur South Kalimantan Public Health Center. The purpose of this research is to identify the factors related to the incidence of anemia for adolescent girls in Tatah Makmur South Kalimantan Public Health Center.

Technology or Method: The type of research is an analytic observation with cross-sectional study design. Samples taken as many as 60 adolescent girls obtained by using random sampling. Method of processing and data analysis using univariate analysis, bivariate analysis, multivariate analysis.

Result: Respondents were 60 adolescent girls with 63,3\% suffering from anemia, $60 \%$ of respondents had enough knowledge, $53 \%$ of respondents had consumption level of deficit category, nutritious category $(51,7 \%)$ and respondents were having menstruation $(63,3 \%)$. From bivariate analysis, the association of anemia on the level of knowledge about anemia, the level of iron consumption and nutritional status is significantly related to menstruation. Multivariate analysis showed that the incidence of anemia did not have a significant relationship with nutritional status and menstruation.

Conclusion: A Nutritional status that is directly related to the incidence of anemia is the need to consume foods containing vitamin $\mathrm{A}$ and $\mathrm{C}$ and contain iron $(\mathrm{Fe})$ is high. Menstruation that affects the incidence of anemia seen from how long the adolescent girls experience menstruation that affects the incidence of anemia experienced by adolescent girls.
\end{abstract}

Keywords: anemia, adolescent girls, consumption of iron, menstruation

\section{INTRODUCTION}

Anemia is a state of the body characterized by a deficiency in the size and amount of erythrocytes or at insufficient hemoglobin levels for the $\mathrm{O}_{2}$ and $\mathrm{CO}_{2}$ exchange functions between the blood tissues. Anemia is still a major health problem in Indonesia besides the problem of less protein energy, less vitamin A and less iodinerelated disorders [1]. Based on Department of
Health, adolescence is a period in which a person experiences progress to achieve mental, emotional, social and physical maturity [2]. The existence of cycle menstruation every month is one of the factors that cause adolescent girls susceptible to iron deficiency anemia. From the Riskesdas, the prevalence of adolescent anemia in Banjar District in 2013 shows 56\% of adolescent girls are still iron nutritional anemia and one of Public Health Center's program in 
2013 examining Hb's adolescent girls at Tatah Makmur South Kalimantan Public Health Center.

Based on the problems, the formulation of the problem in this study is what factors are associated with the incidence of anemia at the Tatah Makmur South Kalimantan Public Health Center. The purpose of this study was to determine the factors associated with the incidence of anemia of adolescent girls in Tatah Makmur South Kalimantan Public Health Center.

\section{Anemia}

The anemia is a condition of less than normal hemoglobin $(\mathrm{Hb})$ levels based on age, sex and pregnancy. The definition of anemia is a condition where the hemoglobin level decreases so that the body will experience hypoxia as a result of the reduced capacity of transporting $\mathrm{O}_{2}$ by the blood.

Adolescent girls experience anemia as they grow rapidly, the amount of iron intake is not enough to keep pace with growth and need more nutrients. In the case of adolescent girls, they need more iron after puberty and have anemia ratio due to lack of blood during heavy menstrual periods.

Adolescent girls who suffer from anemia initially in the form of fatigue, fatigue, loss of appetite or reduced, decreased concentration and headache, especially when risen from the seat. In addition, the mucous membranes of the eyelid, face, lips, and nails appear pale, the tongue feels hot, dry and sore when exposed to food. In more severe cases, shortness and possible weakness of the heart [3].
According to the Ministry of Health in 2003, the impact of anemia on the age of adolescent girls is the declining ability and concentration of learning, disrupt the growth so that the body does not reach optimal, decreased physical ability sportsman and resulted in a pale face. Iron nutrient anemia $(\mathrm{Fe})$ is the core of the hemoglobin molecule that is a major element in red blood cells, the lack of iron nutrient supply leads to decreased hemoglobin production. As a result of the reduction of size (microcytic), low hemoglobin (hypochromic) and red blood cell count [4]. Hemoglobin ( $\mathrm{Hb})$ is a complex protein composed of globin protein and an open protein compound called hem [5]. Iron is a necessary substance in the formation of blood synthesis of hemoglobin $(\mathrm{Hb})$ [6]. The total amount of iron in the body an average of 4-5 grams, approximately $65 \%$ found in the form of hemoglobin, about $4 \%$ in the form of myoglobin and $15-30 \%$ mainly stored in the liver especially in the form of ferritin [7].

\section{Level of knowledge about anemia}

Knowledge is the result of knowing and this happens after people make sense to a particular object. A convincing thing about the importance of nutritional knowledge is based on the fact that nutritional status is important for health and well-being. The theory of Suhardjo suggests that an important cause of nutritional disorders including iron nutritional anemia is a lack of knowledge about nutrition and applying it to everyday life [8]. This is in accordance with the theory that knowledge possessed by a person is 
the basis of doing, therefore the ability of someone to do something depends on the knowledge they have.

\section{Consumption of Iron Food with Anemia}

The most common type of anemia is iron deficiency, which occurs when we lose a lot of blood from the body (either due to wound hemorrhage or due to menstruation) or because the foods we consume contain less iron. There are several stages of our body iron deficiency. Initially, the deposits of iron in the body decrease. With reduced iron, the production of hemoglobin and red blood cells was reduced [9]. Unhealthy adolescent girls behavior that anemia can also be caused by various factors. Teenager girls are at high risk of anemia, especially lack of iron because of adolescent girl's experience very rapid growth. In body growth requires nutrients in large quantities and among them is iron. When iron is used for growth less than the body produces, anemia occurs.

\section{Nutrition Status with Anemia Occurrence}

Nutrition status is a state of the body of a person or group of people as a result of consumption, absorption, and use of nutrients the body generally leads to a good nutritional status [10]. Health and personal health disorders of a person, a group of people or society as a result of an imbalance between intake with the body's need for food and the influence of disease interaction (infection) is a nutritional problem. The existence of some of these imbalances can lead to less nutrition and more nutrition. The nutritional status of adolescent girls in Indonesia is lack of macronutrients (carbohydrate, protein, and fat), lack of micronutrients (vitamins and minerals). Lack of maximal and micronutrient nutrients causes the body to become thin and the weight drops drastically short anemia, pain continuously so as an unhealthy mother candidate [11].

\section{Menstruation}

According to the theorist states that young women who have experienced menstruation are more susceptible to iron anemia because the amount of blood lost during a menstrual period of 12,5 to $15 \mathrm{mg} / \mathrm{month}$ [12]. Menstruation is the collapse of endometrial epithelial tissue due to the influence of female hormonal reproductive health changes. Adolescent girls who have had menstruation will generally lose iron by 0.48 mg/day [13]. The anemia caused by menstruation is strongly influenced by the duration of menstruation, menstrual cycle and menstrual frequency [14].

\section{RESEARCH METHODS}

The population this research is 150 adolescent girls Area in Tatah Makmur South Kalimantan Public Health Center. The sample in this study is as many as 60 adolescent girls. The research design used was cross-sectional where the measurement of the variables was done only once, at a time [15]. The research location in Tatah Makmur South Kalimantan Public Health Center. 
Independent variables are a level of knowledge about anemia, Levels of iron consumption, nutritional status, and menstruation. The dependent variable is the incidence of anemia. The research instrument in this research is laboratory test, Hb's level, anthropometric measurement (IMT), 1 x 24-hour food record form and questionnaires.

Primary data were obtained from a laboratory test of $\mathrm{Hb}$ 's degree of adolescent girls, IMT measurement, 1 x 24-hour food record and questionnaires. The secondary data obtained by way of monograph data recorded Tatah Makmur South Kalimantan Public Health Center.

The characteristics of respondents in this study are shown in Table 1.

Table 1. Characteristics of Respondents

\begin{tabular}{|c|c|c|c|c|}
\hline No & $\begin{array}{c}\text { Characteristics } \\
\text { of respondents }\end{array}$ & Category & Amount & $\begin{array}{c}\text { Percentage } \\
(\%)\end{array}$ \\
\hline \multirow{2}{*}{1} & \multirow{2}{*}{$\begin{array}{c}\text { Total number of } \\
\text { teachers }\end{array}$} & $\begin{array}{c}\text { Government } \\
\text { employees }\end{array}$ & 3 & 15 \\
\cline { 3 - 5 } & $\begin{array}{c}\text { Temporary } \\
\text { employees }\end{array}$ & 17 & 85 \\
\hline \multirow{2}{*}{2} & \multirow{2}{*}{ Adolescent girls } & 15 years & 13 & 22 \\
\cline { 3 - 5 } & & 16 years & 27 & 45 \\
\cline { 3 - 5 } & & 17 years & 17 & 28 \\
\cline { 3 - 5 } & & 18 years & 3 & 5 \\
\hline
\end{tabular}

\section{Data Analysis}

\section{Univariate Analysis}

In this analysis, the data were taken using the descriptive statistical test to see the distribution of the incidence of anemia, level of knowledge about anemia, the level of iron consumption, the nutritional status and menstruation in the adolescent girls in The Tatah Makmur South Kalimantan Public Health Center.

2. Bivariate Analysis
The Bivariate Analysis in this study was conducted to see a relationship between independent variables with the dependent variable, the statistical test used in this study is Chi-Square Test. Where if the value of $p$-value $(<0.05)$ stated there is a meaningful relationship and $p$-value $(>0,05)$ stated there is no significant relation. The purpose of this analysis is to measure the closeness of the relationship between the observed results of the population possessed by two variants (bivariate).

\section{Multivariate Analysis}

The analysis used is multiple linear regression points to know the variables that influence. The analysis used when the independent variable numerical scale, ordinal and nominal while the variable depends on the nominal scale dichotomy [16].

\section{RESULT}

\section{Univariate Analysis}

The Table 2 shows that girls who the incidence of anemia is $63,3 \%$, adolescent girls who have level knowledge about anemia is enough $60 \%$, level of iron consumption $(\mathrm{Fe})$ have deficit $53 \%$ with nutritional status $51,7 \%$ and when the adolescent girls who experience menstruation as many as 34 people $(46,7 \%)$.

Table 2. Frequency Distribution of Respondents by Occurrence of anemia, Knowledge of Anemia, Fe Feet Level, Nutritional Status and Menstruation

\begin{tabular}{|c|l|c|c|c|}
\hline No & \multirow{2}{*}{$\begin{array}{c}\text { Variables } \\
\text { Studied }\end{array}$} & Category & $\begin{array}{c}\text { Amount } \\
\mathbf{n = 6 0}\end{array}$ & $\begin{array}{c}\text { Percentage } \\
(\mathbf{\%})\end{array}$ \\
\hline \multirow{2}{*}{1} & \multirow{2}{*}{$\begin{array}{l}\text { The incidence } \\
\text { of anemia }\end{array}$} & Anemia & 38 & 63,3 \\
\cline { 3 - 5 } & & Not anemia & 22 & 36,7 \\
\hline \multirow{2}{*}{2} & $\begin{array}{l}\text { Level of } \\
\text { knowledge }\end{array}$ & Good & 8 & 13 \\
\cline { 3 - 5 } & & Enough & 36 & 60 \\
\hline
\end{tabular}




\begin{tabular}{|c|l|c|c|c|}
\hline \multirow{2}{*}{3} & about anemia & Less & 16 & 27 \\
\hline \multirow{2}{*}{3} & Levels of iron & Medium & 16 & 27 \\
\cline { 3 - 5 } & & Less & 12 & 20 \\
\cline { 3 - 5 } 4 & $\begin{array}{l}\text { consumption } \\
\text { nutritional } \\
\text { status }\end{array}$ & Neficit & 32 & 53 \\
\cline { 3 - 5 } & Thin & 31 & 51,7 \\
\hline \multirow{2}{*}{5} & Menstruation & Menstruation & 34 & 46,7 \\
\cline { 3 - 5 } & $\begin{array}{c}\text { Not } \\
\text { Menstruation }\end{array}$ & 26 & 43,3 \\
\hline
\end{tabular}

The above table shows that girls who the incidence of anemia is $63,3 \%$, adolescent girls who have level knowledge about anemia is enough $60 \%$, level of iron consumption $(\mathrm{Fe})$ has deficit $53 \%$ with nutritional status $51,7 \%$ and when the adolescent girls who experience menstruation as many as 34 people $(46,7 \%)$.

\section{Bivariate Analysis}

Table 3 shows the correlation between two interrelated variables. From the Table 4 above note that:

a. The incidence of anemia (y) with level knowledge of anemia $\left(\mathrm{x}_{1}\right)$ has a significant value of $0,000<0,05$ which means there is a significant correlation.

b. The incidence of anemia (y) incidence with the level of iron consumption $\left(\mathrm{x}_{2}\right)$ has significant value $0,000<0,05$ which means there is a significant correlation.

c. The incidence of anemia (y) with nutritional status $\left(\mathrm{x}_{3}\right)$ has a significant value of $0,048<$ 0,05 which means there is a significant correlation.

d. Furthermore, the incidence of anemia (y) with menstruation $\left(\mathrm{x}_{4}\right)$ has a significant value of $0,258>0,05$ which means there is no significant correlation.

\section{Statistical Test of Kendal Tau}

Table 5 shows the Kendall's Tau Correlation. From the Table 4 shows that:

a. For Pearson's R-value of 0,369 with Sig. (2tailed) of 0,000 or less than 0,05 , it was decided that the incidence of anemia (y) and level knowledge of anemia $\left(\mathrm{x}_{1}\right)$ were significantly and significantly correlated.

b. For Pearson's R-value of 0.475 with Sig. (2tailed) of 0,000 or less than 0,05 , it was decided that the incidence of anemia (y) and levels of iron consumption $\left(\mathrm{x}_{2}\right)$ were significantly and significantly correlated.

c. For Pearson's R-value of 0.178 with Sig. (2tailed) of 0,050 or less than 0,05 , it was decided that the incidence of anemia (y) and nutritional status $\left(\mathrm{x}_{3}\right)$ were significantly and significantly correlated.

d. For the value of Pearson's $r$ of $(-0,112)$ with Sig. (2-tailed) of 0,300 or greater than 0,05 , it was decided that the incidence of anemia (y) and menstruation $\left(\mathrm{x}_{4}\right)$ were not significantly and significantly related. 
Table 3. Correlations

\begin{tabular}{|c|c|c|c|c|c|c|}
\hline & & $\begin{array}{c}\text { Kejadian } \\
\text { Anemia }\end{array}$ & $\begin{array}{c}\text { Tingkat } \\
\text { Pengetahuan } \\
\text { tentang Anemia }\end{array}$ & $\begin{array}{c}\text { Tingkat } \\
\text { Konsumsi } \\
\text { Zat Besi }\end{array}$ & Status Gizi & Menstruasi \\
\hline \multirow[t]{3}{*}{ Kejadian Anemia } & $\begin{array}{l}\text { Pearson } \\
\text { Correlation }\end{array}$ & \multirow[b]{3}{*}{60} & & &, $256^{*}$ &,- 148 \\
\hline & Sig. (2-tailed) & &, 000 &, 000 & ,048, & 258, \\
\hline & $\mathrm{N}$ & & 60 & 60 & 60 & 60 \\
\hline \multirow[t]{3}{*}{$\begin{array}{l}\text { Tingkat Pengetahuan } \\
\text { tentang Anemia }\end{array}$} & $\begin{array}{l}\text { Pearson } \\
\text { Correlation }\end{array}$ & $450^{* *}$ & \multirow[t]{3}{*}{1} &, $329^{*}$ & ,225 &,$- 339^{* *}$ \\
\hline & Sig. (2-tailed) &, 000 & &, 010 & 085 &, 008 \\
\hline & $\mathrm{N}$ & 60 & & 60 & 60 & 60 \\
\hline \multirow[t]{3}{*}{$\begin{array}{l}\text { Tingkat Konsumsi Zat } \\
\text { Besi }\end{array}$} & $\begin{array}{l}\text { Pearson } \\
\text { Correlation }\end{array}$ &, $707^{* *}$ & \multirow{3}{*}{$\begin{array}{r}329^{*} \\
010 \\
60 \\
\end{array}$} & \multirow[t]{3}{*}{1} &, $360^{* *}$ &,- 074 \\
\hline & Sig. (2-tailed) &, 000 & & &, 005 &, 573 \\
\hline & $\mathrm{N}$ & 60 & & & 60 & 60 \\
\hline \multirow[t]{3}{*}{ Status Gizi } & $\begin{array}{l}\text { Pearson } \\
\text { Correlation }\end{array}$ & ,256* & \multirow{3}{*}{$\begin{array}{r}, 225 \\
, 085 \\
60 \\
\end{array}$} & \multirow{3}{*}{$\begin{array}{r}, 360^{* *} \\
, 005 \\
60 \\
\end{array}$} & 1 &,$- 266^{*}$ \\
\hline & Sig. (2-tailed) &, 048 & & & &, 040 \\
\hline & $\mathrm{N}$ & 60 & & & 60 & 60 \\
\hline \multirow[t]{3}{*}{ Menstruasi } & $\begin{array}{l}\text { Pearson } \\
\text { Correlation }\end{array}$ &,- 148 &,$- 339^{* *}$ & \multirow{3}{*}{$\begin{array}{r}-, 074 \\
, 573 \\
60\end{array}$} &,$- 266^{*}$ & 1 \\
\hline & Sig. (2-tailed) & ,258 &, 008 & &, 040 & \\
\hline & $\mathrm{N}$ & 60 & 60 & & 60 & 60 \\
\hline
\end{tabular}

**. Correlation is significant at the 0.01 level (2-tailed).

*. Correlation is significant at the 0.05 level (2-tailed).

Table 4. Kendall's Tau Correlations

\begin{tabular}{|c|c|c|c|c|c|c|c|}
\hline & & & $\begin{array}{l}\text { Kejadian } \\
\text { Anemia }\end{array}$ & $\begin{array}{c}\text { Tingkat } \\
\text { Pengetahuan } \\
\text { tentang Anemia }\end{array}$ & $\begin{array}{c}\text { Tingkat } \\
\text { Konsumsi Zat } \\
\text { Besi } \\
\end{array}$ & Status Gizi & Menstruasi \\
\hline \multirow[t]{15}{*}{$\begin{array}{l}\text { Kendall's } \\
\text { tau_b }\end{array}$} & \multirow[t]{3}{*}{ Kejadian Anemia } & \multirow{3}{*}{$\begin{array}{l}\text { Correlation } \\
\text { Coefficient } \\
\text { Sig. (2-tailed) } \\
\mathrm{N}\end{array}$} & \multirow[t]{3}{*}{1,000} &, $369^{* *}$ &, $475^{* *}$ &, 178 &,- 112 \\
\hline & & & & ,000 &, 000 & ,050 &, 300 \\
\hline & & & & 60 & 60 & 60 & 60 \\
\hline & \multirow{3}{*}{$\begin{array}{l}\text { Tingkat } \\
\text { Pengetahuan } \\
\text { tentang Anemia }\end{array}$} & \multirow{3}{*}{$\begin{array}{l}\text { Correlation } \\
\text { Coefficient } \\
\text { Sig. (2-tailed) } \\
\mathrm{N}\end{array}$} & \multirow{3}{*}{$\begin{array}{r}369^{* *} \\
, 000 \\
60 \\
\end{array}$} & 1,000 &, $387^{* *}$ &, $229^{*}$ &,$- 275^{*}$ \\
\hline & & & & & ,000 & ,018 & ,017 \\
\hline & & & & 60 & 60 & 60 & 60 \\
\hline & \multirow{3}{*}{$\begin{array}{l}\text { Tingkat } \\
\text { Konsumsi Zat } \\
\text { Besi }\end{array}$} & $\begin{array}{l}\text { Correlation } \\
\text { Coefficient }\end{array}$ & \multirow{3}{*}{$\begin{array}{r}, 475^{* * *} \\
, 000 \\
60 \\
\end{array}$} &, $387^{* *}$ & 1,000 &, $302^{* *}$ &,- 064 \\
\hline & & Sig. (2-tailed) & &, 000 & & ,001 & ,550 \\
\hline & & $\mathrm{N}$ & & 60 & 60 & 60 & 60 \\
\hline & \multirow[t]{3}{*}{$\overline{\text { Status Gizi }}$} & $\begin{array}{l}\text { Correlation } \\
\text { Coefficient }\end{array}$ & , 178 & ,229* &, $302^{* *}$ & 1,000 &,$- 244^{*}$ \\
\hline & & Sig. (2-tailed) & 050 & ,018 & ,001 & & 025 \\
\hline & & $\mathrm{N}$ & 60 & 60 & 60 & 60 & 60 \\
\hline & \multirow[t]{3}{*}{ Menstruasi } & $\begin{array}{l}\text { Correlation } \\
\text { Coefficient }\end{array}$ & \multirow{3}{*}{$\begin{array}{r}-, 112 \\
, 300 \\
60\end{array}$} &,$- 275^{*}$ &,- 064 &,$- 244^{*}$ & 1,000 \\
\hline & & Sig. (2-tailed) & & ,017 & ,550 & ,025 & \\
\hline & & $\mathrm{N}$ & & 60 & 60 & 60 & 60 \\
\hline
\end{tabular}

**. Correlation is significant at the 0.01 level (2-tailed).

*. Correlation is significant at the 0.05 level (2-tailed). 
Table 5. Coefficients ${ }^{\mathrm{a}}$

\begin{tabular}{|c|c|c|c|c|c|c|}
\hline \multirow{2}{*}{\multicolumn{2}{|c|}{ Model }} & \multicolumn{2}{|c|}{ Unstandardized Coefficients } & \multirow{2}{*}{$\begin{array}{l}\text { Standardized } \\
\text { Coefficients } \\
\text { Beta }\end{array}$} & \multirow[b]{2}{*}{$\mathrm{t}$} & \multirow[b]{2}{*}{ Sig. } \\
\hline & & $\mathrm{B}$ & Std. Error & & & \\
\hline \multirow[t]{5}{*}{1} & (Constant) & 8,213 & 1,550 & & 5,300 & 000 \\
\hline & $\begin{array}{l}\text { Tingkat Pengetahuan } \\
\text { tentang Anemia }\end{array}$ & ,020 & ,009 & ,237 & 2,343 & ,023 \\
\hline & Tingkat Konsumsi Zat Besi & 045 & ,007 & ,640 & 6,342 &, 000 \\
\hline & Status Gizi &,- 024 & ,068 &,- 035 &,- 352 & ,726 \\
\hline & Menstruasi &,- 107 & ,353 &,- 030 &,- 302 & ,764 \\
\hline
\end{tabular}

a. Dependent Variable: Kejadian Anemia

Based Table 5 using multiple linear regression test showed that the level of iron consumption $(\mathrm{Fe})$ has a significant relationship with the incidence of anemia in adolescent girls because it has a value of beta coefficient ( $\beta)$ larger $(0,640)$, with $p=0,000(p<0,05)$ and the level of knowledge about anemia significant relation with the incidence of anemia in adolescent girls because it has value beta coefficient $(\beta)$ bigger $(0,237)$, with value $p$ $=0,023(\mathrm{p}<0,05)$ while nutritional status have $p=0,726(p>0,05)$ and menstruation with $p$ value $=0,764(p>0,05)$. So the nutritional status and menstruation there is no significant relationship with the incidence of anemia in adolescent girls in Tatah Makmur Public Health Center.

\section{DISCUSSION}

The weakness of this research is that there is one independent variable which has no significant relation with the independent variable. The dependent variable is menstruation. Menstruation has no connection with the occurrence of anemia. The results of this study indicate the causes of anemia occurring in adolescent girls is knowledge of female teenage anemia, Fe consumption level, and nutritional status.

The menstrual pattern is not the only cause of anemia. Research ever conducted by Gibney mentions there are anemia risk factors that include increased loss (menstruation), poor iron stores, nutritional insufficiency and increased needs [17]. Based on multiple linear regression analysis above shows that menstruation does not significantly affect the incidence of anemia.

Factors associated with anemia are vitamin An intake, vitamin $\mathrm{C}$ asbapan and iron intake. In this study, the relationship between anemia incidence is not significant with nutritional status, this is influenced by factors that have been investigated by Kirana which states not all nutritional status affect the incidence of anemia. Only vitamins $\mathrm{A}$ and $\mathrm{C}$ and iron (Fe) that directly affect [18].

There is an urgent need to develop interventional programmes in these slum areas in the form of nutritional supplementation along with prophylaxis of iron-folic acid tablets for prevention of anemia. Regular nutritional education sessions should be carried 
out to increase awareness in adolescent girls regarding anemia [19].

Another study conducted by Yamin also states there is no relationship between the pattern of menstruation with the incidence of iron nutritional anemia in adolescent girls in a high school of Selayar Islands. Conducted on the research obtained the factors that influence anemia include: adolescent girl's knowledge, protein intake, iron intake, dad's job, work Mother, and father's education level.

Other research results that are in line with this research are research conducted by Siahaan which Said that there is no significant relationship between the pattern of menstruation and the incidence of anemia in adolescent girls in Depok City Region in 2011 with a value of $p=0,756$. This study mentions the factors that affect anemia include: adolescent girls' knowledge, protein intake, iron intake, father work, Mother's job [20].

Many factors have been shown to influence anemia in adolescent girls. They include teenage, socio-economic status, hormonal changes, and excessive blood flow to menstruation, diet and open-air defecation and bare foot walking. The study from Iran had shown that the traditional eating habit contributes to the development of anemia super added with other associated factor. This study had also demonstrated that the odds' ratio was not significantly associated with a single factor. These findings are also in corroboration with the other study in Sanliurfa where the high rate of red meat consumption had a low incidence of anemia [21]. Similar things are met by Kanodia et al. Who studied the incidence of anemia in adolescent girls in Nepal influenced by factors like diet (vegetarian/ non-vegetarian), worm infestation and parental education did not have a significant impact on the occurrence of anemia [22]. A high prevalence of anemia among adolescent girls was found, which was higher in low economic strata. It was seen that anemia affects the overall nutritional status of adolescent girls [23]. Association between anemia and under-nutrition has been reported earlier in numerous studies; however present study highlights the fact that it is not common to have anemia among girls who are over nourished or obese. Hence, special efforts should be made to address this issue among girls by doing dietary modifications [24].

Subsequent research object of the study can be categorized for adolescent girls based on age level with multivariate analysis for each category of age.

\section{Conclusions}

Respondents were 60 people with $63,3 \%$ suffering from anemia, $60 \%$ of respondents had enough level knowledge of anemia, 53\% of respondents had a level of iron consumption of deficit category, nutritional status $(51,7 \%)$ and respondents were having menstruation $(63,3 \%)$. From bivariate analysis, the incidence of anemia with the level of knowledge about anemia, the level of iron consumption and nutritional status is significantly related than 
menstruation. Multivariate analysis showed that the incidence of anemia did not have a significant relationship with nutritional status and menstruation.

\section{ACKNOWLEDGMENT}

We would like to thank Tatah Makmur Public Health Center for permits to conduct research and have been allowed to see the production process and get the data at the time of the preliminary study

\section{REFERENCES}

[1] Almatsier S. Prinsip dasar ilmu gizi. Gramedia Pustaka Utama, 2002.

[2] Khomson. Kesehatan D. Pedoman penanggulangan anemia gizi untuk remaja putri dan wanita usia subur. Jakarta: Departemen Kesehatan RI, 2003.

[3] Lisdiana. Waspada Terhadap Kekurangan Gizi. Jakarta: Penerbit Dian Rakyat, 2009.

[4] Harli Mohammad. Mengatasi Anemia Kurang Besi. [online] 2004. Avalaible from: URL:http://www.indonesia.com. Accessed October 10, 2014.

[5] Sadikin, M. Biokimia Darah. Jakarta: Widya Medika, 2006.

[6] Djaeni, A. Kesehatan Remaja dan Faktor-Faktor yang Mempengaruhi. Jakarta: Salemba Medika, 2004.

[7] Guyton. Fisiologi Kedokteran. Jakarta: EGC; 2004

[8] Suharjo. Prinsip-Prinsip Ilmu Gizi. Yogyakarta: Konisius, 2007.

[9] Utamadi, Mulyono. Kesehatan Remaja, Jakarta: Penerbit Sagung Seto, 2008.

[10] Suhardjo. Penilaian Status Gizi. Jakarta: EGC, Jakarta, 2003.

[11] Caroline. Nutrition in Women Health. Aspek Publisher Maryland [online] 200. Available from URL: www.caroline.weblog.com. Accesses July 1, 2011.
[12] Arisman. Buku Ajaran Ilmu Gizi. Gizi dalam Daur Kehidupan. PT. Gramedia, 2008.

[13] WHO. Pelayanan Kesehatan Anak Remaja. Jakarta: EGC, 2001.

[14] Affandi S. Gangguan Haid pada Remaja dan Dewasa. Jakarta: Balai Penerbit FKUI, 2004.

[15] Sofyan. Prosedur Penelitian. Jakarta: EGC, 2002.

[16] Sastroasmoro. Dasar-Dasar Metodologi Penelitian Klinis. Jakarta: Penerbit CV. Sagung Seto, 2011

[17] Gibney J. Michael. Gizi Kesehatan Masyarakat. Jakarta: EGC, 2009.

[18] Kirana, Dp. Hubungan Asupan Zat Gizi dan Pola Menstruasi dengan Kejadian Anemia pada Remaja Putri di SMAN 2 Semarang, Universitas Diponegoro, Semarang. Available from URL: http://eprints.indip.ac.id/35294/1/395_Di an_Purwitaningtyas_Kirana_G2C007022 .pdf. Accessed February 23, 2014.

[19] Mallikarjuna M., Geetha H. Prevalence and Factors Influence Anemia among Adolescent Girls: A Community Based Study. Int J Sci Res, 4: 1032-1034, 2013.

[20] Siahaan NR. Faktor-Faktor yang Berhubungan dengan Status Anemia pada Remaja Putri di Wilayah Kota Depok Tahun 2011 (Analisis Data Sekunder Survey Anemia Remaja Putri Dinas Kesehatan Kota Depok Tahun 2011). Universitas Indonesia. [online] 2012. Available from URL: http://lib.ui.ac.id/file?file $=$ digital $/ 202930$ 28-S-

Nahsty\%20Raptauli\%20Siahaan.pdf. Accessed December 14, 2013.

[21] Kulkani M.V., Durge P. M., Kasturwar N.B. Prevalence of Anemia Among Adolescent Girls in An Urban Slum. Nat J Community Med,; 3: 108-111, 2012.

[22] Kanodia et al. A Study of Anemia among Adolescent Girls in Eastern Part of Nepal. J Coll Med Sci, 12; 19-22, 2016.

[23] Siddharam S.M., Venkatesh G.M., Thejeshwari H.L. A Study of Anemia Adolescent Girls in Rural Area of Hasan District Karnakan, South India, Int J Bio Med Res,.2(4); 922-924, 2011. 
[24]A.S., Chauhan, S.R., Chauhan, D.V., Bala, 2015, Anemia among Adolescent Girls and Its Socio-Demographic Associates, Int Mult J Health, 1; 1-8, 2015. 